Adam Grzeliński

Uniwersytet Mikołaja Kopernika, Toruń

ORCID: 0000-0002-4007-6507

e-mail: adamgrz@umk.pl

\title{
Filozofia po reformie - uzupełniające się perspektywy
}

Jednym z zakładanych przez twórców wprowadzonej w 2019 roku reformy szkolnictwa wyższego celów jest podniesienie jego jakości w taki sposób, by polskie badania zyskały odpowiednie (czytaj: odpowiednio wysokie) miejsce w obiegu międzynarodowym. Często jednak można usłyszeć zarówno hurraoptymistyczne głosy, które podkreślają konieczność takiego procesu, jak i - równie donośne - głosy sprzeciwu. Z jednej strony twierdzi się zatem, że pora wyjść z zaścianka, z drugiejże proces ten prowadzić będzie do zniweczenia dotychczasowych wartościowych osiągnięć poprzez bezmyślne wcielanie w życie sztucznych rozwiązań. Jestem przekonany, że przynajmniej do pewnego stopnia skrajności opinii można byłoby uniknąć, gdybyśmy zwrócili uwagę na to, że w owych ocenach zwykle bierze się pod uwagę różny dystans czasowy, a także uwzględnia dwie uzupełniające się perspektywy dotyczące badań - ich znaczenie dla rodzimego środowiska i obieg międzynarodowy. Chodzi mianowicie o konieczność odróżnienia niedogodności, usterek i błędów dotyczących wprowadzania ustawy (dotyczących sposobu wprowadzania reformy, narzędzi oceny dyscyplin, sporządzania wykazu czasopism czy wydawnictw naukowych) oraz skutków bardziej długofalowych, a także dwóch różnych ról, jakie pełni filozofia (szerzej - humanistyka), sprowadzających się zarówno do kształtowania rodzimej kultury, jak i do aktywnego uczestnictwa w międzynarodowym życiu naukowym. 


\section{Maszeruj albo giń}

Wspomnianej sztuczności rozwiązań można upatrywać w wymuszaniu publikacji w języku angielskim (niekiedy całkowicie zbędnym), wykorzystaniu niedoskonałych kryteriów oceny (nieprzystających do polskich warunków baz indeksacyjnych czasopism), mierzeniu liczby cytowań za pomocą narzędzi, które nie tylko nie uwzględniają specyfiki nauk humanistycznych, ale także w niewielkim stopniu oddają rzeczywistość (chociażby Google Scholar). Ponadto wskazuje się na dwie dość oczywiste wady sposobu wprowadzania reformy.

Pierwsza jest pośpiech, któremu zdaje się towarzyszyć przeświadczenie twórców reformy, że albo wprowadzi się ją natychmiast, albo straci impet i rozmieni się na drobne w ciągu kolejnych poprawek, aż w końcu będzie miała jedynie charakter fasadowy. W efekcie reguły ewaluacji dyscyplin naukowych w postaci wykazu punktowanych czasopism i wydawnictw znane są dopiero $\mathrm{w}$ połowie okresu podlegającego ocenie. Chociaż jestem przekonany, że np. wymóg przedstawienia do oceny dyscypliny 4 publikacji w ciągu 4 lat jest ogólnie łatwy do spełnienia przez każdego aktywnego badacza co do zasady, to argument krytyczny dotyczący pośpiesznego wprowadzenia nowych reguł oceny jest $\mathrm{w}$ tym przypadku celny. Drugi zarzut dotyczy sposobu przygotowania ministerialnych list punktowanych czasopism i wydawnictw. Uwzględniono mnóstwo wydawnictw niewielkich i szerzej nieznanych, zrównując je co do liczby punktów z największymi wydawnictwami krajowymi, w związku z czym cała punktozowa zabawa straciła sens. Miałaby go, gdyby bardziej zróżnicować oceny, a także do węższego grona wysoko punktowanych wydawców dopisać kilka najlepszych polskich wydawnictw, ale także poszerzyć listę o najlepszych wydawców obcych, lecz nieanglojęzycznych. Ewidentnie tego zabrakło. Z perspektywy polskiej filozofii dobrze się stało, że skorygowano ów wykaz tak, że znalazły się na nim Wydawnictwo Marek Derewiecki, Academicon czy Officyna. Inny problem dotyczy ewaluacji czasopism. Na ministerialnej liście obejmującej gigantyczną liczbę tytułów nie znalazła się spora liczba pism, które jakością nie ustępują innym, ale nie spełniły wymaganych kryteriów, takich jak obecność w bazach Scopus i Web of Science lub ERIH PLUS (w tym przypadku dochodziła merytoryczna ocena środowiskowa). Rzecz w tym, że aplikacja do pierwszych dwóch wymaga czasu, którego wielu czasopismom zabrakło.

O ile zarzut pierwszy ma charakter tymczasowy, jeśli podczas kolejnej ewaluacji nie zmienią się ponownie kryteria oceny, o tyle zarzut drugi jest poważniejszy - czasopisma, które nie znalazły się na ministerialnej liście, są - by użyć ewolucyjnego porównania - mocno zagrożone wyginięciem ze względu na warunki finansowe i punktowo-publikacyjne. 
Oczywiście rzecz nie w tym, by koniecznie miało istnieć tak wiele czasopism jak dotychczas, ale $\mathrm{w}$ tym, że niekiedy przyczyny niemożności umieszczenia konkretnego tytułu w wykazie czasopism punktowanych były dość przypadkowe, jak znalezienie się na liście ERIH PLUS. Jak pamiętamy, obecność w tej bazie była kilka lat temu promowana wysoką punktacją artykułów, które ukazywały się w pismach przez ERIH PLUS indeksowanych, choć zarazem wskazywano - poniekąd słusznie że wymaga to spełnienia jedynie pewnych kryteriów formalnych, a nie jakościowych. W ostatnich latach obecność w tej bazie nie miała znaczenia dla wysokości ministerialnej punktacji. Nagle jednak okazało się, że przy obecnej ewaluacji czasopism indeksowanie przez ERIH PLUS jest warunkiem koniecznym, aby dany tytuł mógł być dodany do ministerialnej listy na podstawie oceny eksperckiej. Kto zdążył - wygrał.

Chociaż ogólne dążenie do zwiększenia widoczności publikacji na arenie międzynarodowej i wprowadzenie polskich periodyków do światowego obiegu - choćby częściowo i poprzez tak formalne działania jak umieszczenie ich w bazach indeksacyjnych - jest słuszne, to wydaje się, że sposób wprowadzenia nowej ewaluacji zawierał nazbyt wiele elementów przypadkowych. Oczywiście, zapobiegliwość czy to badaczy publikujących także za granica, czy to redakcji czasopism, które dbają o to, aby nadążać za zmieniającymi się sposobami funkcjonowania, jest chwalebna. Nie sposób jednak nie odnieść wrażenia, że skala wprowadzonych zmian (duża rozpiętość punktacji czasopism i wydawnictw) powoduje, że jest to ewaluacja szczególna: rzecz nie dotyczy bowiem, jak dotychczas, zmiany punktacji z 8 na 10 punktów, ale prawdziwego być albo nie być pism i wydawnictw. W tej sytuacji o obecności pisma czy wydawnictwa na liście ministerialnej nie powinien decydować przypadek.

\section{Dwie perspektywy czasowe i dwa zagrożenia}

Kieruje to uwagę na fakt, że wskazywane usterki bądź - na odwrót szanse wynikające z funkcjonowania filozofii „po reformie” często odnoszą się do bardzo różnych perspektyw czasowych. Ze względów oczywistych dużo błędów i idących za nimi głosów krytycznych dotyczy perspektywy najbliższej: pospiesznego wprowadzania zmian w połowie okresu podlegającego najbliższej ewaluacji. W dalszej perspektywie rzeczywiście można mówić również o pozytywnych skutkach reformy: wymuszeniu aktywizacji naukowej osób, które publikują bardzo mało lub zgoła wcale, promowaniu umiędzynarodowienia badań, a także konieczności spełnienia przez czasopisma i wydawnictwa podstawowych wymogów formalnych (takich jak odpowiednie procedury recenzowania, regularność ukazywania się). Wydaje się zresztą, że twórcy refor- 
my właśnie tę dalszą perspektywę uznali za podstawowa, a obiecana lepsza przyszłość miałaby przy tym usprawiedliwić przejściowe usterki i błędy. Warto jednak wskazać na pewne niebezpieczeństwa związane z takim myśleniem.

Podstawowe zagrożenie dotyczy odwrócenia hierarchii środków i celów. Otóż zgodnie z oficjalną wykładnią ministerialną wprowadzona właśnie reforma ma przeciwdziałać punktozie, tj. nadmiernej liczbie niskopunktowanych publikacji, zjawisku, w którym chociaż każda z publikacji z założenia ukazuje się w kiepskich miejscach (cokolwiek by to nie miało znaczyć), to suma punktów za sporą liczbę takich publikacji jest już akceptowalna i przekłada się niezłą ocenę badacza. Jak sądzę, takie rozumowanie zawiera kilka błędów, choć zapewne sprawdzenie tego przypuszczenia wymagałoby szczegółowych uzasadnień, na które nie ma tu miejsca (dodajmy jednak, że zakłada ono przystawalność jakości naukowej i wysokości punktacji za publikacje, pomija natomiast fakt, że ci, którzy publikują mało, publikują mało niezależnie od tego, gdzie publikują i za ile punktów). Chodzi jednak o rzecz bardziej zasadniczą: o to, że wymogi instytucjonalne - ocena dyscypliny, a w dalszej konsekwencji hierarchizacja uniwersytetów - powoduja, że powodem publikacji nie jest ogłoszenie wyników badań, ale zdobycie punktów. Ostatecznie celem działań staje się to, co powinno być środkiem - punktacja, która nie jest niczym innym, jak próbą zestandaryzowania czegoś tak niewymiernego, jak osiągnięcie naukowe, po to, aby móc porównać ze sobą elementy układanki instytucjonalnej - pracowników, ośrodki naukowe, dyscypliny, uniwersytety. Ponieważ zaś owo zestandaryzowanie potrzebne jest ze względu na podział środków na badania - zarówno $\mathrm{w}$ procedurach grantowych, jak i codziennej praktyce uniwersyteckiej ostatecznym realnym działaniem jest obieg twardej punktozowej waluty, badania zaś i ich efekty stają się niejako efektem ubocznym owych praktyk.

Przeciwko takiej pesymistycznej interpretacji można oczywiście wysunąć dwie obiekcje. Pierwsza głosi, że ostatecznie jakieś kryteria oceny parametrycznej są niezbędne i że dwa porządki: wartości naukowej oraz indywidualnej i instytucjonalnej ewaluacji $\mathrm{w}$ ostatecznym rozrachunku powinny się zbiegać - przynajmniej po wprowadzeniu niezbędnych korekt w przypadku jaskrawych niedostatków, o których wspomniałem powyżej. Choć diabeł tkwi w szczegółach, to przynajmniej można starać się zminimalizować jego działania. Oto druga obiekcja: skoro jakieś - oby jak najlepsze - wymogi ewaluacji ostatecznie muszą istnieć, to należy je przyjąć, ale poza tym i niejako obok tego prowadzić badania, których wartość nie przekłada się na punkty. Jeśli mielibyśmy pozostać $\mathrm{w}$ tej samej poetyce, moglibyśmy powiedzieć, że sytuacja wymusza co prawda zapalenie ogarka bibliometrycznym wymogom (choćby pełnym szatańskich usterek), ale pozostawia możliwość zapalenia w zbożnym 
celu świeczki na biurku, na którym prowadzi się prace ważne, choć nieprzekładające się na ewaluacyjną walutę.

$\mathrm{O}$ ile z pierwszą obiekcją jestem skłonny do pewnego stopnia się zgodzić, o tyle z drugą już nie. To racja, że wymóg zapełnienia 4 slotów publikacyjnych faktycznie jest niewygórowany i pozostawia czas na badania i publikacje inne, mniej punktowane; zasadna wydaje się także konieczność przedstawienia publikacji przez wszystkich pracowników naukowych. Kłopot jednak w tym, że w sytuacji ograniczonych środków projekty cenne dla kultury, ale nisko punktowane po prostu nie będą finansowane, bo okres zwrotu poniesionych nakładów jest bardzo krótki, wyznaczony najbliższą ewaluacją dyscyplin. Czas, po którym znaczenie takich prac może przynieść ewaluacyjnie wymierne skutki, często wielokrotnie przekracza ów okres. Może się zatem okazać, że owej świeczki nie da się już zapalić.

Kolejne zagrożenie dotyczy działalności publikacyjnej, która należy do podstawowej pracy naukowej i choć sama nie jest może spektakularna, to umożliwia pojawienie się prac powszechnie czytanych i szeroko komentowanych. Chodzi o czasopiśmiennictwo oraz wyraźnie niedocenioną przez twórców reformy edycję źródeł oraz działalność translatorską. Z oczywistych względów w kolejnych latach czasopism naukowych będzie mniej. Niektóre znikną nie tylko dlatego, że nie dorównały kroku lepszym i zostały zamknięte; będzie ich mniej także i z tego prostego względu, że w wyniku ograniczenia wymaganej liczby publikacji mniej będzie tekstów zgłaszanych do czasopism. Zapewne ograniczenie liczby periodyków było jednym z zamysłów twórców reformy, skoro np. zeszłoroczny ministerialny program wsparcia czasopism humanistycznych i kulturalnych ogłoszony przez Ministerstwo Kultury i Dziedzictwa Narodowego wpisywał się w limity pomocy de minimis i obejmował tylko tytuły, które dostały się na listę ministerialną. Niektóre pisma z powodów formalnych nie mogły zatem ubiegać się o finansowanie z tego źródła: selekcja dokonała się wcześniej. Oczywiście istnieje nikła szansa, że tytuły, które nie znalazły się na liście ministerialnej, czas do momentu kolejnej oceny wykorzystają do podniesienia jakości. Będzie to jednak wysiłek iście herkulesowy, skoro publikacja w nich nie przekłada się na ewaluacyjne pieniądze.

Drugim, co najmniej tak samo istotnym, obszarem prac są przekłady literatury i krytyczne edycje źródeł. Niestety, gromko ogłaszane przez MNiSW docenienie ich znaczenia jest zupełnie gołosłowne. Ponieważ za publikację przekładu przysługuje 25\% punktów, które można uzyskać za wydanie monografii, w praktyce najpewniej żadna tego rodzaju publikacja nie będzie zgłaszana do ewaluacji, bo wszystkie zostaną wyparte przez monografie i artykuły w czasopismach. Nie martwiłbym się przy tym o to, czy znajdą się chętni do przygotowywania edycji i przekładów, bo taka praca zawsze była wynikiem czyjejś pasji, a nie kalkulacji. 
Kłopotem jest jednak możliwość wydania takich prac z powodów finansowych. Mało rozbudowany system grantowy (sprowadzający się zasadniczo do konkursu Uniwersalia 2.2 Narodowego Programu Wspierania Humanistyki oraz działalności nielicznych fundacji) może stanowić jedynie bardzo niewielką pomoc, a uczelniom zainteresowanym przede wszystkim zdobyciem punktowego „kapitału” rzecz po prostu nie będzie się nijak opłacać, bo finansowanie takich publikacji będzie oznaczało wyrzucanie je w ewaluacyjne błoto. Dobro kultury, nawet doceniane, może być zbyt odległe, a koszty muszą zwracać się szybko, przy najbliższej ewaluacji.

\section{Różne, uzupełniające się cele}

Hurraoptymizm zwolenników reformy i kasandryczne głosy jej przeciwników wskazują na dość prosty fakt, że praca naukowa służy różnym celom, które - jestem o tym przekonany - nie są wzajemnie przeciwstawne, lecz uzupełniają się. Pierwszym z nich jest poszerzanie poznania na najwyższym możliwym poziomie, poszerzanie, które nie jest możliwe bez udziału $\mathrm{w}$ międzynarodowym obiegu badawczym. To oczywiste i wie o tym każdy, kto brał udział chociażby w specjalistycznych konferencjach naukowych, podczas których spotykają się najlepsi badacze $\mathrm{z}$ różnych krajów - w tym gronie rzeczywiście istotne są najważniejsze osiągnięcia, a wyniki badań przedstawia się z reguły w językach innych niż polski. Dlatego publikacje w języku obcym oraz w czytanych czasopismach zagranicznych mają oczywiście sens choćby i z tego powodu, że bardzo zaawansowane, szczegółowe badania skierowane są niekiedy do wyselekcjonowanego, wąskiego grona odbiorców - dobrze zatem, jeśli mogą być czytane przez innych specjalistów na świecie, bo w Polsce mogą przydać się niekiedy jedynie kilku osobom.

Istnieje jednak drugi cel pracy naukowej, jakim jest kształtowanie rodzimej kultury filozoficznej. Znaczący jest tu fakt, że filozofia przypisana jest do dziedziny nauk humanistycznych, choć oczywiście jest to przypisanie nie do końca oddające jej specyfikę (inaczej sytuowane w jej obrębie są np. logika i historia filozofii, a i w tej ostatniej istotne mogą być różnice chociażby pomiędzy historią filozofii niemieckiej i polskiej). Oznacza to, że - inaczej niż w przypadku nauk ścisłych - w filozofii mamy do czynienia nie tylko z wyborem pomiędzy "pierwszym frontem badań", najnowszymi zdobyczami wiedzy osiągniętymi w ścisłej współpracy międzynarodowej i popularyzacją która stanowi upraszczające przedstawienie owych zdobyczy. Istnieje bowiem jeszcze cała sfera pośrednia - tworzenie kultury filozoficznej, do którego należy życie środowiska naukowego, kształtowanie języka filozoficznego czy przyswajanie, rozwijanie i krytykowanie osiągnięć światowych. Każda 
próba wyrugowania jednego z tych dwóch obszarów będzie prowadzić do niepożądanych następstw - zaniku rodzimej kultury bądź zasklepienia się w niej. Uczestniczymy w różnych obiegach naukowych, a nasze publikacje mają różnych czytelników.

\section{Postscriptum}

Wypowiedzi uczestników panelu „Filozofia w Polsce po reformie”, który odbył się podczas 11 Zjazdu Filozoficznego w Lublinie, ukazują się w Ruchu Filozoficznym. W imieniu redakcji kwartalnika chciałbym bardzo serdecznie podziękować Autorom za nadesłanie rozszerzonych wersji swych wystąpień. Ufam, że przyczynią się do ożywienia dyskusji w środowisku filozoficznym, i zachęcam do kolejnych wypowiedzi oraz polemik.

$\mathrm{Z}$ uwagi na miejsce, w którym ukazują się te wypowiedzi, na koniec chciałbym wspomnieć o tym, jak na sytuację filozofii patrzymy z perspektywy naszego czasopisma. Ruch Filozoficzny usytuowany jest bowiem w szczególny sposób: wydawany jest dość lokalnie (czy „niemetropolitalnie"), bo w Toruniu, ale pozostaje również organem Polskiego Towarzystwa Filozoficznego. Jest jednym z najstarszych polskich czasopism filozoficznych, ale stara się nadążać za najnowszymi wymogami, takimi jak elektroniczny obieg czytelniczy, rozwijanie współpracy międzynarodowej i obecność w cenionych bazach indeksacyjnych. Być może ta dość specyficzna perspektywa sprawia, że kiedy dyskutowaliśmy w redakcji o roli, jaką powinien pełnić kwartalnik, doszliśmy do wniosku, że powinna ona polegać na godzeniu skrajności. Staramy się zatem z jednej strony propagować to, co rodzime i bliskie - stąd na przykład jubileuszowe, tematyczne numery czasopisma poświęcone postaciom Kazimierza Twardowskiego i Romana Ingardena. $Z$ drugiej jednak strony systematycznie wydajemy dwa numery czasopisma rocznie w języku angielskim, udostępniając łamy także badaczom spoza Polski. Staramy się, aby poza prostym spełnieniem wymogów formalnych działalność ta docelowo służyła realnemu wprowadzeniu polskich badań do obiegu światowego. Ostatecznie Ruch Filozoficzny pełnił zawsze rolę integrująca środowisko - pragniemy w redakcji, aby tak było i teraz, w nowych warunkach, w których warto zachowywać to, co cenne w rodzimym dziedzictwie filozoficznym, ale też $\mathrm{w}$ których naturalne jest dbanie o obecność polskiej filozofii także w świecie. Jestem przekonany, że te dwa cele nie wykluczają się. 